\title{
Characteristics of Biometallic Alloy to Additive Manufacturing Using Selective Laser Melting Technology
}

\author{
Marcello Vertamatti Mergulhão, Maurício David Martins Das Neves \\ Material Science and Technology Center, Nuclear and Energy Research Institute, Sao Paulo, Brazil \\ Email: marcellovertamatti@usp.br
}

How to cite this paper: Mergulhão, M.V. and Das Neves, M.D.M. (2018) Characteristics of Bimetallic Alloy to Additive Manufacturing Using Selective Laser Melting Technology. Journal of Biomaterials and Nanobiotechnology, 9, 89-99.

https://doi.org/10.4236/jbnb.2018.91008

Received: November 13, 2017

Accepted: January 28, 2018

Published: January 31, 2018

Copyright ( 92018 by authors and Scientific Research Publishing Inc. This work is licensed under the Creative Commons Attribution International License (CC BY 4.0).

http://creativecommons.org/licenses/by/4.0/

\begin{abstract}
Biomaterial powders are in high development due to expansion of additive manufacturing (AM) processes. Selective laser melting (SLM) is a particular AM technology, which completely melts a powder bed layer by laser beam. Investigations of appropriated physical properties of feedstock (powder alloy) were the aim of this study. Cobalt-chromium-molybdenum (Co-Cr-Mo) alloy was used to overview of gas-atomized powder properties in different granulometric ranges (D1 $12-19 \mu \mathrm{m}, \mathrm{D} 220-46 \mu \mathrm{m}$ and D3 $76-106 \mu \mathrm{m}$ ), as their: physical, chemical properties and thermal analysis. SLM manufactured standard tensile specimens of usually granulometric range powder size provided mechanical, chemical and thermal properties of biocompatible Co-Cr-Mo alloy. The physical properties showed that powders in the range of 20 to $50 \mu \mathrm{m}$ provide a better flow ability and packed density, which are relevant characteristics to SLM processing. Manufacturing by SLM process provided suitable mechanical properties in the health area, as well as, maintained the biocompatible properties of the Co-Cr-Mo alloy.
\end{abstract}

\section{Keywords}

Biomaterial, Co-Cr-Mo Alloy, Powder Alloy, Additive Manufacturing, Selective Laser Melting

\section{Introduction}

Biocompatibility properties of Co-Cr alloys provided to these super alloys a wide range of application in the health area [1]. Associated with high wear and adequate corrosion resistances, medical components were widely produced by conventional techniques, as casting and cold or hot forming followed by posting 
process (milling and thermal treatments) [2]. AM processes are routes of increasing development which save and waste time, material and costs during parts fabrications.

The selective laser melting (SLM) is a technology that can manufacture 3D components by laser beam action that completely melts a powder bed layer until the final geometry. Traditional SLM machines have a maximum laser power of $400 \mathrm{~W}$ with laser focus diameter of $100 \mu \mathrm{m}$ can be provided by a source of Ytterbium fiber. SLM process occurs layer by layer using a feedstock as a metal powder that is stored in a container that may be the distributor of powder (deposited by gravity), which turn to uniform the powder layer (between 20 to $100 \mu \mathrm{m}$ ) on the build platform [3].

A relevant feature in the AM processes which may influence the mechanical properties of parts manufactured is the material characteristics (powder). The metal powder must present specific characteristics of: size, shape, granulometric distribution and physical properties (flowability and packing). Powder bed fusion methods can be employed with different granulometric powders sizes [4] [5] [6]. In the process SLM is notable the use of gas-atomized powders, has better physical characteristics of powders processed than water atomization. Several authors describe the performance SLM parts using powders alloys at the range of 20 to $50 \mu \mathrm{m}$ [4] [5]. The system using electron beam source, as know by electron beam melting (EBM) is widely developing with particles of 76 to $106 \mu \mathrm{m}$. The effects and influence of the powder reused on manufactured parts is the subject of many discussions. This topic is relevant in the EBM (Electron Beam Melting) process using Ti-alloys part off by the aggregate cost of manufactured parts [5] [6] [7].

The production of metal components by laser melting was promising since it allows the manufacture of customized components and your higher final physical properties when compared to conventional techniques [8] [9]. There is an important knowledge to understand the powder properties, to correlation with the dimensional, mechanical and microstructural characterization in the consolidation of specimens with this technology, as reported recently [8] [9] [10].

The aim of this study is to analyse the physical characteristics of powders in different granulometric ranges and to point out the factors that influence the properties of the powders, in order to reveal the better granulometric range for the SLM process. The study primarily focuses on the analyses physical characteristics of ASTM F75 powders. Powders characteristics as a granulometric size, particle format, flow rate, apparent, tap, theoretical and helium pycnometry densities were evaluated. SLM processing standard specimens to evaluated mechanical properties and thermal stability of biocompatible Co-Cr-Mo alloy.

\section{Materials and Methods}

\subsection{Powder Characterization}

Co-Cr-Mo alloy gas atomized (H.C Starck ${ }^{\circledR}$, Germany) was provided by the High-

Bond $^{\circledR}$ (Indaiatuba, Brazil) in three different granulometric range, respectively by 
terminologies: D1 $(12-19 \mu \mathrm{m}), \mathrm{D} 2(20-46 \mu \mathrm{m})$ and D3 $(76-106 \mu \mathrm{m})$. The confirmation of the chemical composition was realised by fluorescence spectrometer X-ray energy dispersive (Shimadzu EDX-720 equipment). This study was based on alloy/powder with certification in a medical device registration and approval in Brazil (ANVISA-National Health Surveillance Agency) for use in health care and meets the ASTM 75 [11].

Several physical properties of gas-atomized powders were obtained such as flow time, apparent density and tap density, respectively according to ASTM B212 [12], ASTM B213 [13] and ASTM B527 [14]. The particle size distribution was performed using a particular analyser by laser scattering (Cilas-Model 1064). The particle format was analysed by scanning electron microscopy (SEM-Philips XL30). The density characterization by Helium pycnometry was performed in the Co-Cr-Mo powders using the Micromeritics machine (Model Accu PYC 1330 Pycnometer).

To evaluate the internal porosity of powders sample were measured the Helium pycnometry in comparison by the theoretical density. The density by pycnometry considered only the internal porosity (excluding the open porosity) and for this purpose was utilized the Micromeritics equipment (Model Accu PYC 1330 Pycnometer).

The hardness of the powders in relation to the granulometric range from the gas atomization process, micro hardness measurements were performed on CoCr-Mo powder samples. The micro hardness tests were performed using a Fischerscope HM2000 equipment with a load of 100,000 mN (micro Newton) for 10 seconds.

\subsection{Sample Consolidation and Analysis}

The consolidation of SLM samples was carried out by SLM Solutions ${ }^{\mathrm{TM}}$ using a $\mathrm{SLM}^{\circledR} 280 \mathrm{HL}$ machine with a single Ytterbium laser beam (maximum power 400 W). SLM processing used the D2 powder at the distribution size of 20 to $46 \mu \mathrm{m}$. The building consolidation of specimens was parallel of laser bean and performed using as parameters: layer thickness of $30 \mu \mathrm{m}$ and diameter of laser beam of $76 \mu \mathrm{m}$. Others consolidation parameters were previously pre-selection by manufacturer.

To evaluate the viability of cell growth in the Co-Cr-Mo alloy after the SLM consolidation processes was performed the cytotoxicity analysis, according to ISO 10993-5 [15]. This toxic effect was analysed by quantitative measurement of cell death, inhibition of cell growth and among caused by other effects.

The tensile and three-point bending specimens were manufactured in standard dimensions according to ISO 22674-06 [16] and ASTM B528-12 [17]. The three-point bending test determined the transversal rupture strength (TRS) of Co-Cr-Mo specimens made by SLM.

The dilatometric analysis was performed on SLM samples were analysed in the parallel and transversal building direction (SLM 1-parallel direction and 
SLM 2-transversal direction), as seen in Figure 1. The purpose of this analysis was to measure the coefficient of thermal expansion (CTE). In addition, to observe the thermal behaviour of Co-Cr-Mo alloy the differential scanning calorimetry (DSC) analysis was performed on the sample of gas-atomized D2 powder of the Co-Cr-Mo alloy. The routine of thermal analysis remained the heating rate was from $10^{\circ} \mathrm{C} / \mathrm{min}$ until the temperature of $1300^{\circ} \mathrm{C}$. The equipment used was a Setaram-Setsys 16/18, using a thermocouple rod of $\mathrm{Pt} / \mathrm{Pt} \mathrm{Rh} 10 \%$ under a static atmosphere (argon-99.999\%) to reduce the sample oxidation.

\section{Results and Discussion}

\subsection{Feedstock Material}

The chemical composition by X-ray fluorescence and LECO, as the comparison with the SLM samples manufactured by D2 powder (granulometric size of 20 $46 \mu \mathrm{m}$ ) given in the Table 1 . The results confirm the chemical composition established accordance with the tolerances of standard ASTM F75 [11].

Figure 2 presents the Co-Cr-Mo powders samples with spherical morphology, as well as the presence of satellites. These formations and the spherical morphology

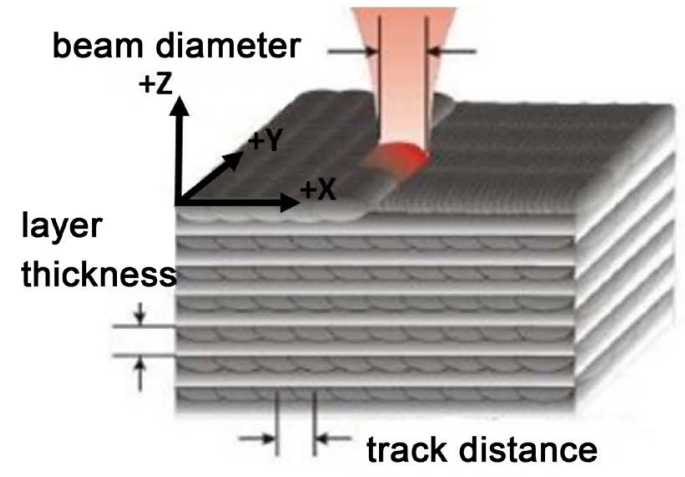

(a)

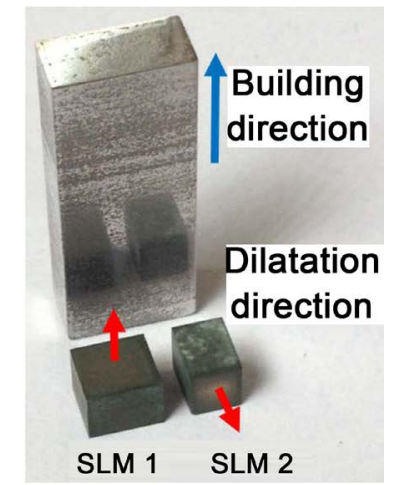

(b)

Figure 1. (a) Schematic of SLM consolidation; and (b) Direction of dilatometry analysis of SLM samples.

Table 1. Chemical composition of Co-Cr-Mo powder and SLM samples by XRF and LECO (elements: $\mathrm{C}, \mathrm{S}, \mathrm{N}_{2}$ and $\mathrm{O}_{2}$ ) in comparison with the standard reference ASTM F75 [11].

\begin{tabular}{cccc}
\hline Elements $(\mathrm{wt} \%)$ & Powder & SLM samples & ASTM F75 \\
\hline $\mathrm{Co}$ & $63.93 \pm 0.16$ & $65.38 \pm 0.32$ & Balance \\
$\mathrm{Cr}$ & $28.83 \pm 0.19$ & $27.68 \pm 0.13$ & $30.00-27.00 \pm 0.30$ \\
$\mathrm{Mo}$ & $7.07 \pm 0.31$ & $6.61 \pm 0.16$ & $7.00-5.00 \pm 0.15$ \\
$\mathrm{Fe}$ & $0.17 \pm 0.01$ & $0.33 \pm 0.06$ & $<0.75 \pm 0.03$ \\
$\mathrm{C}$ & $0.03 \pm 0.010$ & $0.03 \pm 0.01$ & $<0.35 \pm 0.020$ \\
$\mathrm{~S}$ & $0.0002 \pm 0.0001$ & $0.0001 \pm 0.0001$ & $<0.010 \pm 0.003$ \\
$\mathrm{~N}_{2}$ & $0.0018 \pm 0.0001$ & $0.1330 \pm 0.0015$ & $<0.250 \pm 0.020$ \\
$\mathrm{O}_{2}$ & $0.0003 \pm 0.0001$ & $0.0240 \pm 0.0010$ & - \\
\hline
\end{tabular}



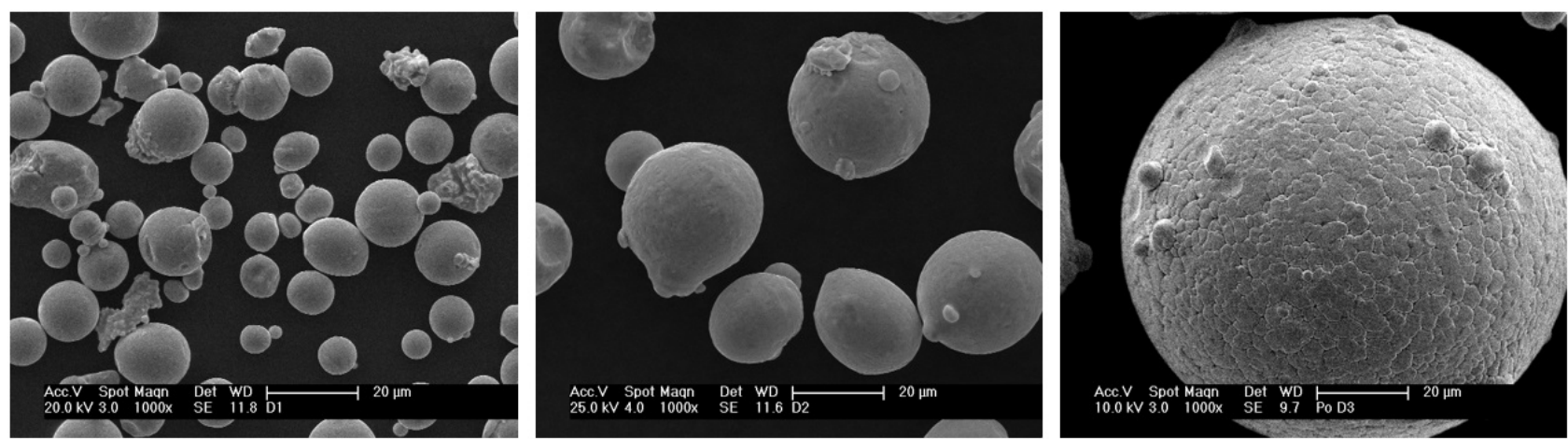

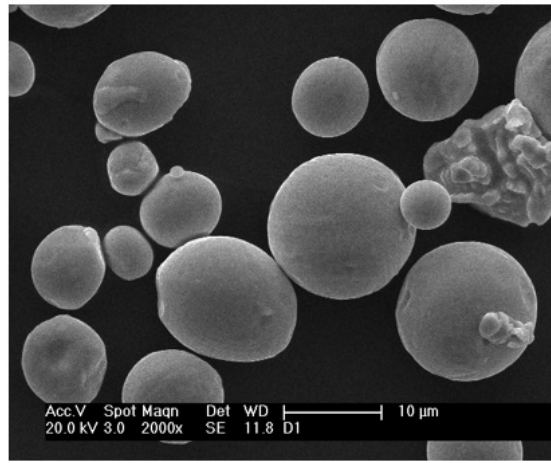

(a)

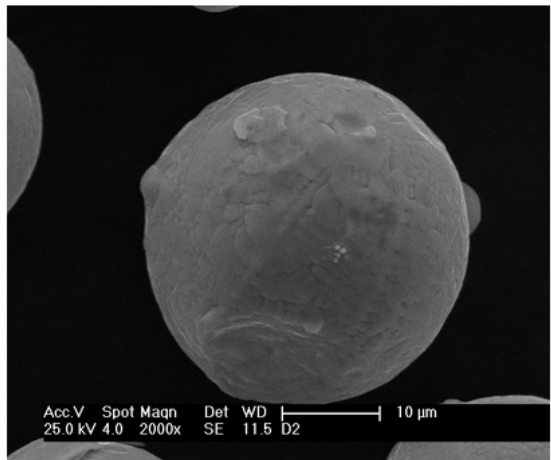

(b)

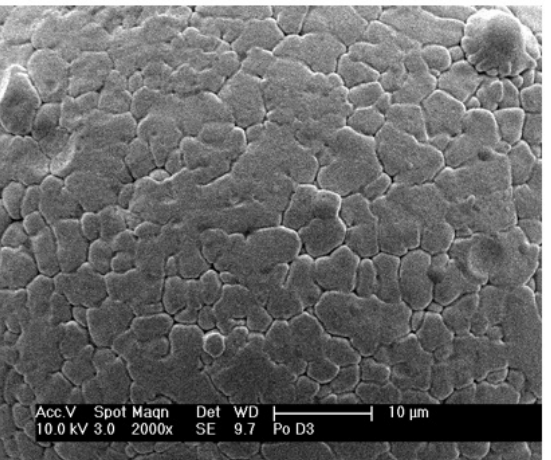

(c)

Figure 2. MEV images of Co-Cr-Mo powders, (a) D1 size; (b) D2 size; and (c) D3 size.

Table 2. Physical properties results of Co-Cr-Mo gas-atomized powders in different granulometric ranges.

\begin{tabular}{cccc}
\hline \multirow{2}{*}{ Physical Properties } & \multicolumn{3}{c}{ Powder } \\
\cline { 2 - 4 } & $\mathrm{D} 1(12-19 \mu \mathrm{m})$ & $\mathrm{D} 2(20-45 \mu \mathrm{m})$ & $\mathrm{D} 3(76-106 \mu \mathrm{m})$ \\
\hline Mean diameter $(\mu \mathrm{m})$ & 12.76 & 32.36 & 92.81 \\
Flow time $(\mathrm{s} / 50 \mathrm{~g})$ & - & $15.85 \pm 0.11$ & $22.89 \pm 0.03$ \\
Apparent density $\left(\mathrm{g} / \mathrm{cm}^{3}\right)$ & $4.12 \pm 0.01$ & $4.51 \pm 0.01$ & $4.55 \pm<0.01$ \\
Tap density $\left(\mathrm{g} / \mathrm{cm}^{3}\right)$ & $5.00 \pm 0.02$ & $5.26 \pm 0.05$ & $5.09 \pm 0.02$ \\
Theoretical density $\left(\mathrm{g} / \mathrm{cm}^{3}\right)$ & & 8.37 & \\
Helium pycnometry density $\left(\mathrm{g} / \mathrm{cm}^{3}\right)$ & $8.28 \pm 0.001$ & $8.30 \pm 0.001$ & $8.27 \pm 0.001$ \\
Hardness $(\mathrm{HV})$ & - & $148.33 \pm 38.89$ & $390.35 \pm 40.73$ \\
\hline
\end{tabular}

are characteristic of the gas atomization process [18].

The physical properties obtained according with powder metallurgy standardizations given in the Table 2 and the granulometric distributions are given in Figure 3.

The sample of the ratio D1 powder having a very fine granulometry and was characterize as no flow powder by Hall flowmeter funnel. Comparing the flow time between D2 powder and D3 powder it is observed that D2 powder had better flowability than D3 powder. The poor flowability of D3 powder was influenced by presence of satellites particles and its superior roughness (can be observed in Figure 2(c)) that narrow the powder mass through the funnel orifice. 


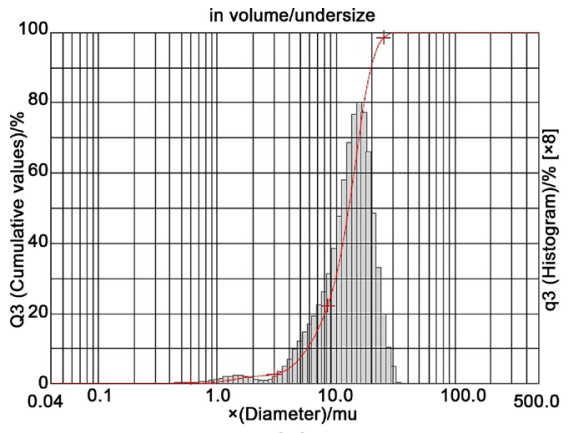

(a)

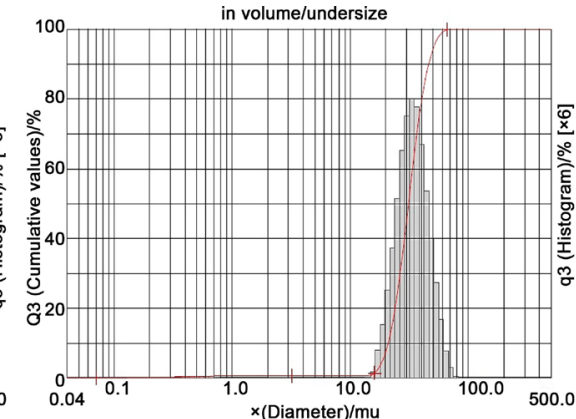

(b)

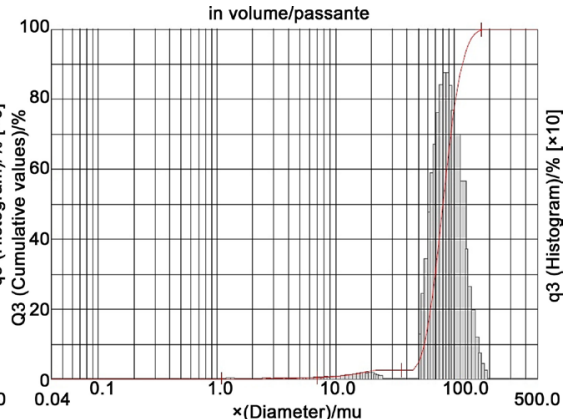

(c)

Figure 3. Granulometric distribution of Co-Cr-Mo powders: (a) D1; (b) D2; and (c) D3.

The apparent density increase was progressive in relation to the granulometric size. This phenomenon is associated with the increase of the specific surface (high friction between the particles) being superior in smaller powders and consequently to hinder the accommodation between the particles [18]. In addition, the flow hate and apparent density are associated to the increases of surface area that stay related to the increases of friction between the particles [18]. The high friction between the particles delays the flow hate of powder as well as the dispersion and accommodation of the particles. In addition, this phenomenon is also observed in the result of tap density. For D2 powder particle because of its smaller specific surface area, it obtained the highest result of beat density (equal to $5.26 \mathrm{~g} / \mathrm{cm}^{3}$ ). According to Haan et al. [19], powder flow time and apparent density of the alloy Co-Cr-Mo study showed relevant results to those obtained respectively for powders with D90 diameter equal to $39 \mu \mathrm{m}$, the flow time was $18.60 \mathrm{~s} / \mathrm{cm}^{3}$ and bulk density was $4.38 \mathrm{~g} / \mathrm{cm}^{3}$.

The Co-Cr-Mo powders characterized by theoretical density related to pycnometer Helium density shows a presence of closed porosity detected. The open porosity is discounted in the pycnometry density. This result considers the presence of closedporosity. The powders samples presented approximately $1.30 \%$ of internal porosity. This result was evidenced comparing the pycnometry density in relation to theoretical density is observed a difference that is correlated to internal porosity.

The micro hardness of powders samples showed that the powder D3 is superior to the result of D2 powder. At the case of D1 powder has a very fine size, the micro hardness cannot be measured. The increment of particle hardness stay associated with the granulometry size and the solidification rate in the gas atomization process. The coarse powder during the fall into the cooling column of atomizer has a higher cooling rate than finer particles. Consequentially, the higher solidification rate will be results in superior hardness values [20].

According to the physical characteristics it was verified that granulometric sizes of 20 to $46 \mu \mathrm{m}$ (D2 powder) can result in better packing and further powder layer densities around $46 \%$ of theoretical density with good flow rate. These characteristics allow better requirements for powder utilized in selective laser melting technology. 


\subsection{SLM Samples}

\subsubsection{Biocompatible Result}

The result of the cytotoxicity analysis for the processed samples is shown in Figure 4. According to the cytotoxicity assay with relation to the pure extract, without dilution, the samples processed by selective laser melting showed no toxicity. $\mathrm{Cy}$ totoxicity assay of Co-Cr-Mo alloy appointed that manufacture SLM specimens can guarantee as a toxic safe material [21].

\subsubsection{Mechanical Analysis}

Tensile stress-strains curves obtained from the tensile tests of SLM specimens are showed in Figure 5(a). The mechanical properties, such as yield strength $(\sigma \mathrm{YS})$, elongation (El), elastic modulus (E), ultimate tensile strength ( $\sigma \mathrm{UTS})$ and

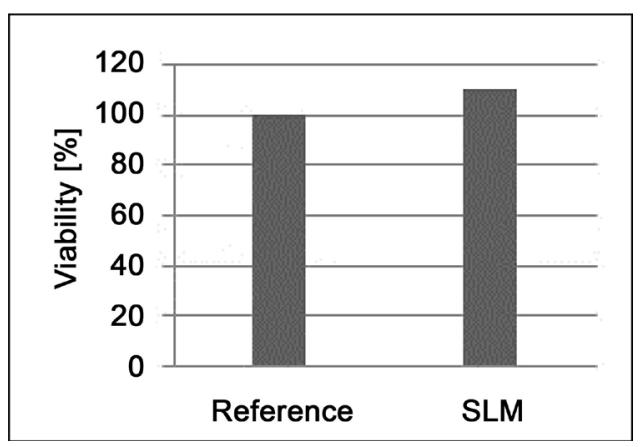

Figure 4. Result of viability of cell growth for Co-Cr-Mo sample manufactured by SLM process.

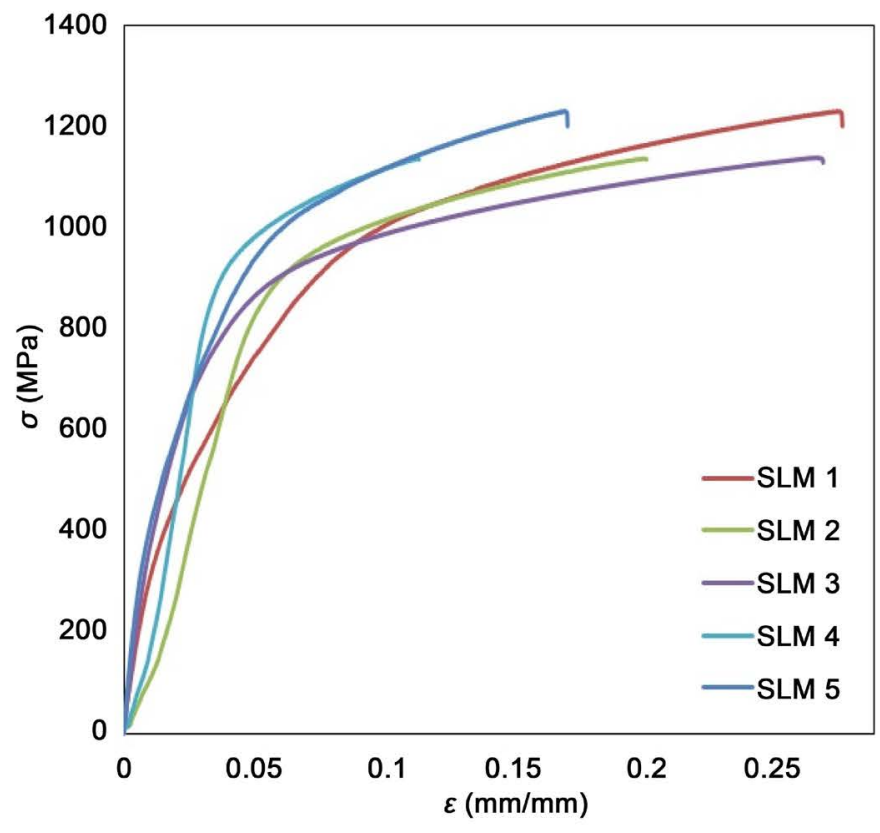

(a)

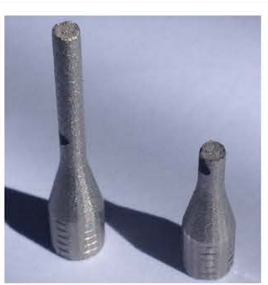

(b)

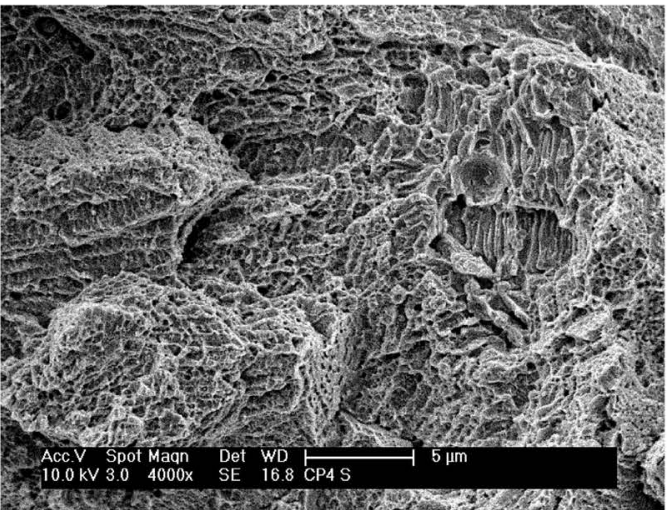

(c)

Figure 5. (a) Tensile stress-strain curves of SLM Co-Cr-Mo specimens; (b) Fracture of tensile specimens; and (c) SEM fractography of SLM specimen. 
Table 3. Results of mechanical properties of SLM samples manufactured by Co-Cr-Mo alloy in comparison with minimum properties of type 5 criteria at ISO 22674.

\begin{tabular}{ccccccc}
\hline Reference & $\sigma \mathrm{YS}[\mathrm{MPa}]$ & $\mathrm{El}[\%]$ & $\mathrm{E}[\mathrm{GPa}]$ & $\sigma \mathrm{UTS}[\mathrm{MPa}]$ & $\sigma \mathrm{r}[\mathrm{MPa}]$ & TRS [MPa] \\
\hline $\begin{array}{c}\text { SLM } \\
\text { Co-Cr-Mo }\end{array}$ & $731.50 \pm 40.31$ & $13.73 \pm 5.32$ & $225.18 \pm 14.40$ & $1136.95 \pm 0.92$ & $1127.91 \pm 0.15$ & $2501.2 \pm 9.7$ \\
$\begin{array}{l}\text { ISO 22674 } \\
\text { (“Type 5”) }\end{array}$ & 500 & 2 & 150 & - & - & - \\
\hline
\end{tabular}

rupture strength ( $\sigma$ ) are summarized in Table 3, as shows the result of transverse rupture strength (TRS). SEM fractures of SLM tensile specimens are showed in Figure 5(b) and Figure 5(c).

Analyzing the values at Table 3 is possible to verify that in all properties the SLM technique satisfied the type 5 criteria in accordance to standard ISO22674:06 [16]. It is verified that the samples have a fragile fracture characteristic, occurring transversal to the tensile stress axis (Figure 5(b)). The fractography (Figure $5(c)$ ) of tensile specimen presented the formation of dimples, which represents a region of greater ductility and toughness. The TRS test results $2501.2 \pm 9.7 \mathrm{MPa}$ was satisfactory in accordance to experimental Menguci et al. [22] results. TRS result for a similar composition of Co-Cr-Mo alloy, after the shoot-peened treatment followed by heat treatment for strain relief, result a TRS equal to 2700 $\pm 25 \mathrm{MPa}$.

\subsubsection{Thermal Analysis}

The thermal analysis curves were obtained from dilatometry (SLM sample) and DSC (D2 powder sample) are presented in Figure 6. To understanding the thermal events and correlated with the analysis the heating curves (CTE vs. DSC) were juxtaposed.

As can be seen at the dilatometric analysis is possible to verify the CTE at temperature of $500^{\circ} \mathrm{C}$ of samples (SLM 1 and SLM 2) are respectively 15.0 and $19.5 \times 10^{-6}{ }^{\circ} \mathrm{C}^{-1}$. At the temperature of $600^{\circ} \mathrm{C}$ the coefficient value decreases to the values of 12.5 and $14.5 \times 10^{-6}{ }^{\circ} \mathrm{C}^{-1}$. The thermal properties are very important for metal materials applied to dental restoration at the temperature range of $500^{\circ} \mathrm{C}$ to $600^{\circ} \mathrm{C}$. The applications of dental restorations required a porcelain coating (copings and crowns) that can be support values of CTE similar to the biomaterial Co-Cr-Mo alloy. Therefore, to avoid the possibility of forming cracks or voids during the coating process [23].

The DSC curve is possible check in the heating curves the presence of events: exothermic approximately at $600^{\circ} \mathrm{C}$, endothermic approximately at $950^{\circ} \mathrm{C}$ and the fusion point of Co-Cr-Mo alloy occurs at $1354^{\circ} \mathrm{C}$. This phenomenon is similar to described by [24], which obtain endothermic peaks, respectively at approximately $970^{\circ} \mathrm{C}$ and $1000^{\circ} \mathrm{C}$, relative to that obtained in the present study of $944^{\circ} \mathrm{C}$. The lower difference in temperature is possible associated with the chemical composition of the alloy (64Co-29Cr-7Mo of the present study), which represent alloys of composition according to ASTM F75 (66Co-28Cr-6Mo). 


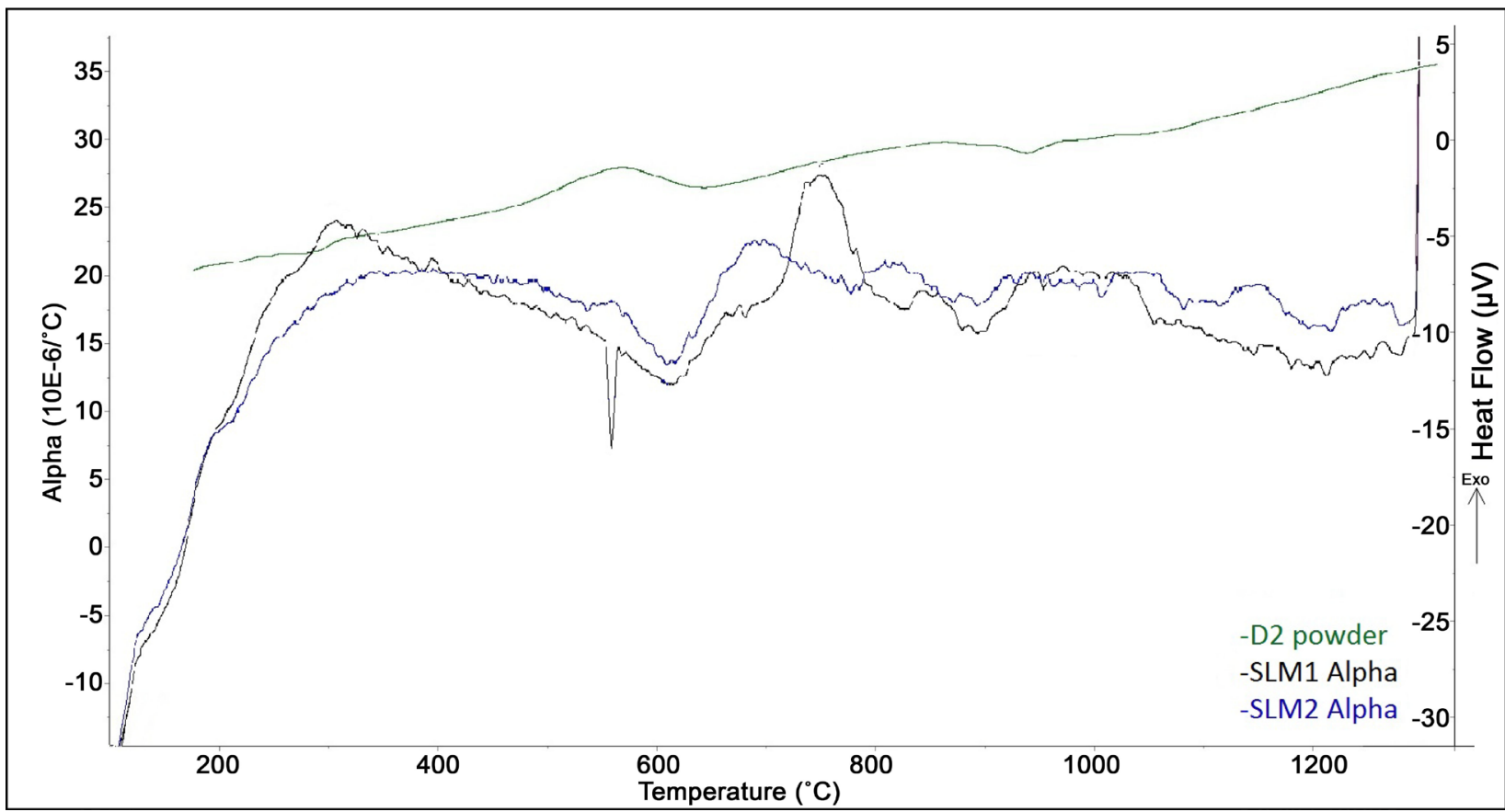

Figure 6. Dilatometric curves of SLM samples (SLM1 and SLM2) and DSC curve Co-Cr-Mo alloy (D2 powder sample). Heating flow of $10^{\circ} \mathrm{C} / \mathrm{min}$, under argon atmosphere.

The first peak (exothermic) occurring approximately at $582^{\circ} \mathrm{C}$ stay associated with the phase transformation of FCC $(\alpha \mathrm{Co})$ to $\mathrm{HCP}(\varepsilon \mathrm{Co})$. The second peak (endothermic) occurring approximately at $944^{\circ} \mathrm{C}$ stay associated with the dissociation of phase HCP to formation of FCC.

These phase transitions represent different behavior of material dilatation, as can be seen at the CTE curve respectively by the dilatations peaks. Therefore, it can be seen from the thermal results that the stability of the Co-Cr-Mo alloy processed by SLM correlates with the phase transitions of the material. In this way, the thermal properties guaranteed the post processing for coating on dental components avoiding defects.

\section{Conclusions}

The particles in the study produced by gas atomization showed spherical particle geometry with satellites and internal porosity. The analysis of the granulometric sizes of powders gave a better understanding of the physical results obtained from some properties of the powders, as can be cited flow hate and densities: apparent, tap and helium pycnometry. In addition, the physical properties evaluated showed that powders in the range of 20 to $46 \mu \mathrm{m}$, provide a better packing results. These powder behaviors are of great importance in the additive manufacturing process using the selective laser melting technology.

Additive manufacturing using selective laser melting of biocompatible Co-CrMo alloy at the range 20 to $46 \mu \mathrm{m}$ allowed obtaining significant mechanical properties qualifying at type 5 of ISO22674 standard. SLM process assures the biocompatibility of Co-Cr-Mo alloy after manufacturing the specimens. In addition, the 
thermal analysis complemented the properties resulting in an interesting point of view to the thermal expansion of the Co-Cr-Mo alloy in different building orientations that are of great importance to manufacture components used in dental area.

\section{Acknowledgements}

The authors would like to thank to Ms. Amed Belaid-SLM ${ }^{\circledR}$ Solutions for SLM specimens and Ms. Carlos E. Podestá-HighBond ${ }^{\circledR}$ for Co-Cr-Mo powder alloy and collaboration. The authors also thanks to PhD. Andrea C. D. Rodas for your contributions and cytotoxicity analysis. This study was financially support by CNPq.

\section{References}

[1] Ivanova, E.P., Bazaka, K. and Crawford, R.J. (2014) Cytotoxicity and Biocompatibility of Metallic Biomaterials. New Functional Biomaterials for Medicine and Healthcare, 2014, 148-172. https://doi.org/10.1533/9781782422662.148

[2] Kim, H.R., Kim, Y.K., Son, J.S., Min, B.K., Kim, K.-H. and Kwon, T.-Y. (2016) Comparison of In Vitro Biocompatibility of a Co-Cr Dental Alloy Produced by New Milling/Post-Sintering or Traditional Casting Technique. Materials Letters, 178, 300-303. https://doi.org/10.1016/j.matlet.2016.05.053

[3] Spears, T.G. and Gold, S.A. (2016) In-Process Sensing in Selective Laser Melting (SLM) Additive Manufacturing. Integrating Materials and Manufacturing Innovation, 5, 2. https://doi.org/10.1186/s40192-016-0045-4

[4] Tang, H.P., Qian, M., Liu, N., Zhang, X.Z., Yang, G.Y. and Wang, J. (2015) Effect of Powder Reuse Times on Additive Manufacturing of Ti-6Al-4V by Selective Electron Beam Melting. JOM, 67, 555-563. https://doi.org/10.1007/s11837-015-1300-4

[5] Slotwinski, J.A., Garboczi, E.J., Stutzman, P.E., Ferraris, C.F., Watson, S.S. and Peltz, M.A. (2014) Characterization of Metal Powders Used for Additive Manufacturing. Journal of Research of the National Institute of Standards and Technology, 119, 460. https://doi.org/10.6028/jres.119.018

[6] Popovich, A. and Sufiiarov, V. (2016) Metal Powder Additive Manufacturing. In: Shishkovsky, I.V., Ed., New Trends in 3D Printing, InTech, Philadelphia.

https://doi.org/10.5772/63337

[7] Sun, J., Yang, Y. and Wang, D. (2013) Mechanical Properties of a Ti6Al4V Porous Structure Produced by Selective Laser Melting. Materials \& Design, 49, 545-552. https://doi.org/10.1016/j.matdes.2013.01.038

[8] Mergulhão, M.V., Podestá, C.E. and Neves, M.D.M. (2017) Valuation of Mechanical Properties and Microstructural Characterization of ASTM F75 Co-Cr Alloy Obtained by Selective Laser Melting (SLM) and Casting Techniques. Materials Science Forum, 899, 323-328. https://doi.org/10.4028/www.scientific.net/MSF.899.323

[9] Mergulhão, M.V., Podestá, C.E. and Neves, M.D.M. (2017) Mechanical Properties and Microstructural Characterization of Cobalt-Chromium (CoCr) Obtained by Casting and Selective Laser Melting (SLM). Materials Science Forum, 899, 534-539. https://doi.org/10.4028/www.scientific.net/MSF.899.534

[10] Mergulhão, M, Eduardo Podestá, C. and Neves, M. (2017) Investigation of Mechanical, Microstructural and Thermal Behavior of CoCrMo Alloy Manufactured by Selective Laser Melting and Casting Techniques. Proceedings of the IX Brazilian 
Congress of Manufacturing Engineering, Joinville-SC, 26-29 June 2017.

[11] ASTM International (2012) F75-12-Standard Specification for Cobalt-28 Chromium-6 Molybdenum Alloy Castings and Casting Alloy for Surgical Implants. ASTM, Pensilvânia.

[12] ASTM International (2013) B212-13-Standard Test Method for Apparent Density of Free-Flowing Metal Powders Using the Hall Flowmeter Funnel. ASTM, Pensilvânia.

[13] ASTM International (2013) B213-13-Standard Test Methods for Flow Rate of Metal Powders Using the Hall Flowmeter Funnel. ASTM, Pensilvânia.

[14] ASTM International (2014) B527-14-Standard Test Method for Determination of Tap Density of Metal Powders and Compounds. ASTM, Pensilvânia.

[15] ISO (1995) 10933-5-Biological Evaluation of Medical Devices-Part 5: Tests for Cytotoxicity: In Vitro Methods. Geneva.

[16] ISO (2006) 22674-06-Dentistry-Metallic Materials for Fixed and Removable Restorations and Appliances. Geneva.

[17] ASTM International (2012) B528-12-Standard Test Method for Transverse Rupture Strength of Powder Metallurgy (PM) Specimens. ASTM, Pensilvânia.

[18] ASM International (1998) Powder Metal Technologies and Applications. Vol. 7. 9th Edition, ASM International.

[19] Haan, J., Asseln, M., Zivcec, M., Eschweiler, J., Radermacher, R. and Broeckmann, C. (2015) Effect of Subsequent Hot Isostatic Pressing on Mechanical Properties of ASTM F75 Alloy Produced by Selective Laser Melting. Powder Metallurgy, 58, 161-165. https://doi.org/10.1179/0032589915Z.000000000236

[20] Gessinger, G.H. (1984) Powder Metallurgy of Superalloys. Butterworth \& Co., Baden.

[21] Xin, X.Z., Xiang, N., Chen, J. and Wei, B. (2012) In Vitro Biocompatibility of Co-Cr Alloy Fabricated by Selective Laser Melting or Traditional Casting Techniques. Materials Letters, 88, 101-103. https://doi.org/10.1016/j.matlet.2012.08.032

[22] Mengucci, P., Barucca, G., Gatto, A., Bassoli, E., Denti, L., Fiori, F., et al. (2016) Effects of Thermal Treatments on Microstructure and Mechanical Properties of a Co-Cr-Mo-W Biomedical Alloy Produced by Laser Sintering. Journal of the Mechanical Behavior of Biomedical Materials, 60, 106-117. https://doi.org/10.1016/j.jmbbm.2015.12.045

[23] Oyagüe, R.C., Sánchez-Turrión, A., López-Lozano, J.F., Montero, J., Albaladejo, A. and Suárez-García, M.J. (2012) Evaluation of Fit of Cement-Retained Implant-Supported 3-Unit Structures Fabricated with Direct Metal Laser Sintering and Vacuum Casting Techniques. Odontology, 100, 249-253. https://doi.org/10.1007/s10266-011-0050-1

[24] Facchini, L. (2010) Microstructure and Mechanical Properties of Biomedical Alloys Produced by Rapid Manufacturing Techniques. PhD Thesis, University of Trento, Trento. 